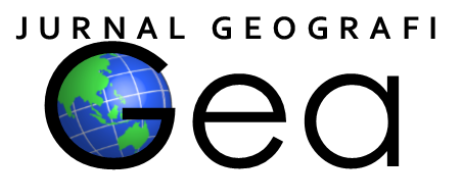

\title{
ANALISIS PENYEBAB BANJIR DI KOTA SAMARINDA
}

\author{
Haris Setiawan', Muhammad Jalil'², Muhammad Enggi ${ }^{3}$, Fathan Purwadi ${ }^{4}$, Christopel \\ Adios $S^{5}$, Asri Wahyu Brata ${ }^{6}$, Andi Syaful Jufda ${ }^{7}$ \\ 1,2,3,4,5,6,7Program Studi Pendidikan Geografi, Fakultas Keguruan dan Ilmu Pendidikan, \\ Universitas Mulawarman \\ 121enggi@gmail.com
}

\begin{abstract}
The purpose of this study was to determine the distribution of floods in Samarinda City, identify the causes of flooding in Samarinda City, and identify the impact of floods on the people of Samarinda City. Samarinda City is an area that is prone to floods. Where the cause of flooding is the problem of flooding in the city of Samarinda due to excessive runoff and inadequate runoff in river bodies so that water overflows. There are two factors that cause flooding in the first city of Samarinda, natural factors such as high rainfall, topography of the region, tides of the Mahakam river, and others. And the second, is human, mainly sourced from the element of population growth will be followed by increased needs for infrastructure, housing, clean water facilities, education, and other community services. In addition, population growth will also be followed by the need for business land for agriculture, plantations, and industry. The sources of inundation (flood) in Samarinda City especially those whose impacts on community activities can be divided into 3 types, namely, due to the Mahakam river tide. The first is flood submissions, the second is local flooding, and the third is flooding due to the Mahakam river tide.
\end{abstract}

Keywords: Cause of floods, Samarinda City, source of inundation.

\begin{abstract}
ABSTRAK
Tujuan penelitian ini adalah untuk mengetahui persebaran banjir di Kota Samarinda, mengindentifikasi penyebab banjir di Kota Samarinda, dan mengindentifikasi dampak banjir terhadap masyarakat Kota Samarinda. Kota Samarinda adalah daerah yang rawan terhadap bencana banjir. Dimana penyebab banjir permasalahan banjir di Kota Samarinda terjadi akibat berlebihnya limpasan permukaan dan tidak tertampungnya limpasan tersebut dalam badan sungai sehingga air meluap. Ada dua faktor yang menyebabkan banjir di Kota Samarinda yang pertama, Faktor alam seperti tingginya curah hujan, topografi wilayah, pasang surut air sungai Mahakam, dan lain-lain. Dan yang kedua, adalah manusia, utamanya bersumber pada unsur pertumbuhan penduduk akan diikuti peningkatan kebutuhan infrastruktur, pemukiman, sarana air bersih, pendidkan, serta layanan masyarakat lainnya. Selain itu pertumbuhan penduduk akan diikuti juga kebutuhan lahan usaha untuk pertanian, perkebunan, maupun industry. Sumber genangan (banjir) di Kota Samarinda khususnya yang dampaknya pada aktivitas masyarakat dapat dibedakan menjadi 3 macam, yaitu, akibat pasang sungai Mahakam.yang pertama banjir kiriman, yang kedua banjir lokal, dan yang ketiga adalah banjir akibat pasang sungai Mahakam.
\end{abstract}

Kata kunci: Penyebab banjir, Kota Samarinda, sumber genangan. 


\section{PENDAHULUAN}

Wilayah Indonesia digolongkan sebagai salah satu negara rawan bencana, baik bencana alam maupun bencana yang diakibatkan oleh kegiatan manusia. Indonesia merupakan Negara kepulauan, secara geografis terletak di persimpangan tiga lempeng utama, lempeng Eurasia di utara dan lempeng Pasifik Timur dan lempeng Indo-Australia di selatan menyebabkan Indonesia rawan terhadap bencana alam seperti gempa bumi, letusan gunung berapi, dan tsunami. Selain itu, sekitar 13 persen dari gunung berapi aktif di dunia yang terletak di sepanjang Kepulauan Indonesia, yang ancaman masyarakat Indonesia dalam bahaya dari berbagai intensitas.

Di sisi lain, bencana merupakan sebuah peristiwa yang sangat akrab dengan masyarakat kita. Banyak yang mengatakan Negara Indonesia adalah surga bencana. Bencana yang sering kita jumpai yaitu banjir. Seiring dengan perkembangan zaman, dalam dunia perdagangan dan bisnis yang kurang memperhatikan aspek kelingkungan.

Indonesia memiliki populasi besar lebih dari 230 juta orang dengan distribusi yang tidak merata, yang terdiri dari berbagai humaniora, agama / keyakinan, budaya, politik, yang dapat menyebabkan munculnya konflik horizontal dan vertikal yang pada akhirnya akan mengarah untuk perpindahan. Selain bencana alam, Indonesia memiliki potensi munculnya bencana buatan manusia sebagai risiko dari beberapa kegiatan yang dapat merusak lingkungan, termasuk penebangan hutan, kebakaran hutan, dan bencana industri.

Banjir yang pada hakekatnya proses alamiah dapat menjadi bencana bagi manusia bila proses itu mengenai manusia dan menyebabkan kerugian jiwa maupun materi. Dalam konteks sistem alam, banjir terjadi pada tempatnya. Banjir akan mengenai manusia jika mereka mendiami daerah yang secara alamiah merupakan dataran banjir. Jadi, bukan banjir yang datang, justru manusia yang mendatangi banjir. Apabila hal tersebut dapat kita terima, maka bencana banjir yang dialami manusia sebenarnya adalah buah dari kegagalan manusia dalam membaca karakter alam. Kegagalan manusia membaca apakah suatu daerah aman atau tidak untuk didiami. Misalnya, kegagalan manusia membaca karakter suatu daerah sehingga tidak mengetahui daerah tersebut merupakan daerah banjir. Banjir adalah suatu bencana yang mengganggu kehidupan manusia berupa genangan air dari yang terkecil sampai terbesar yang disebabkan faktor-faktor baik manusia maupun alam atau aliran air yang tinggi, dan tidak tertampung oleh aliran sungai sehingga air itu meluap ke daratan yang lebih rendah. Menurut Kamus Besar Bahasa

Indonesia (KBBI), banjir adalah peristiwa terbenamnya daratan (yang biasanya kering) karena volume air yang meningkat. Definisi kedua dari kamus tersebut, banjir adalah berair banyak dan deras, kadangkadang meluap.

Samarinda sebagai ibukota Provinsi Kalimnatan Timur merupakan salah satu kota di Indonesia yang memiliki pertumbuhan dan perkembangan pesat. Perkembangan kota ini dipengaruhi oleh laju pertumbuhan penduduk yang mengakibatkan meningkatnya pula kebutuhan lahan perkotaan. Oleh karena itu, tingkat kepadatan di daerah perkotaan cenderung lebih tinggi daripada di wilayah pedesaan karena tingkat aktivitas dalam populasi perkotaan cenderung lebih tinggi. Pengembangan daerah perkotaan dengan perubahan tutupan vegetasi, tanah menjadi permukaan kedap air dengan kapasitas penyimpanan air kecil atau tidak ada. Aktivitas terhadap penggunaan lahan yang paling dominan adalah aktivitas perumahan. Kegiatan ini memakan lebih dari $50 \%$ dari total luas, sehingga sekarang banyak bermunculan daerah pemukiman dengan konsep vertikal untuk.

Secara umum, masalah bencana di Indonesia, khususnya di Kota Samarinda cukup menghawatirkan, dimana becana banjir ini sudah mengakibtakan lumpuhnya aktifitas di Kota Samarinda. Berdasarkan latar belakang di atas, penulis berkeinginan menyusun penelitian tentang Analisis Penyebab Banjir di Kota Samarinda. Tujuan penelitian ini adalah untuk Mengetahui persebaran banjir di Kota Samarinda, Mengindentifikasi penyebab banjir di Kota Samarinda, dan Mengindentifikasi dampak banjir terhadap Masyarakat Kota Samarinda. 


\section{METODE PENELITIAN}

Penelitian ini menggunakan metode kualitatif pada dampak banjir taerhadap fasilitas sekolah dan metode kuantitatif pada dampak terhadap aktivitas pendidikan di Kota Samarinda.

Dalam penelitian ini yang menjadi populasi sasaran adalah masyarakat yang terdampak banjir di Kota Samarinda. Pengambilan sampel dalam penelitian ini dilakukan secara acak yaitu dengan mengambil daerah yang terdampak banjir di Kota Samarinda. Jenis teknik sampling menggunakan cara penentuan anggota sampel secara acak dan sistematik (Systematic Ramdom Sampling). Data yang diperlukan diperoleh melalui observasi, wawancara, dokumentasi, dan angket. Angket.

\section{HASIL DAN PEMBAHASAN}

Parameter-parameter yang digunakan dalam penelitian ini diproyeksikan dalam bentuk peta. Kemudian dilakukan analisis berdasarkan peta tersebut.

\section{- Curah Hujan}

Pembuatan parameter curah hujan bertujuan untuk melihat sebaran rata-rata curah hujan tahunan pada wilayah penelitian. Curah hujan tahunan antara $1.900-2.000 \mathrm{~mm} / \mathrm{tahun}$ memiliki luas 4.371,42 $\mathrm{Ha}$ (6,33\%). Sedangkan sebagian wilayah di Kota Samarinda merupakan daerah dengan rata-rata curah hujan tahunan anatar $2.200-2.300$ $\mathrm{mm} /$ tahun dengan luas wilayah mencapai $37.828,05 \mathrm{Ha}(54,77 \%)$.

Tabel 1. Luas Wilayah Berdasarkan Sebaran Rata-rata Curah Hujan Tahunan di Kota Samarinda dengan Metode Geostatistical Krigging

\begin{tabular}{cccc}
\hline No & $\begin{array}{c}\text { Kelas Rata-rata Curah Hujan } \\
(\mathrm{mm} / \text { tahun) }\end{array}$ & $\begin{array}{c}\text { Luas } \\
\text { Wilayah }\end{array}$ & $\begin{array}{c}\text { Presentase } \\
(\%)\end{array}$ \\
\hline 1 & $1.900-2.000$ & $4.371,42$ & 6,33 \\
2 & $1.900-2.001$ & $7.230,14$ & 10,47 \\
3 & $1.900-2.002$ & $9.565,79$ & 13,85 \\
4 & $1.900-2.003$ & $37.828,05$ & 54,77 \\
5 & $1.900-2.004$ & $10.075,32$ & 14,59 \\
\hline \multicolumn{2}{c}{ Sumber: Jurnal Penelitian Daerah Rawan Banjir di Kota Samarinda Navisatun Halimah }
\end{tabular}

Tabel 2. Rekapitulasi Jumlah Bencana Banjir Di Kota Samarinda

\begin{tabular}{cc}
\hline Banjir Di Kota Samarinda & Tahun \\
\hline 4 & 2014 \\
5 & 2015 \\
1 & 2016 \\
5 & 2017 \\
5 & 2018 \\
20 & 2019 \\
\hline & Sumber: BPBD Provinsi Kaltim
\end{tabular}

Berdasarkan data di atas secara umum permasalahan banjir di Kota Samarinda terjadi akibat berlebihnya limpasan permukaan dan tidak tertampungnya limpasan tersebut dalam badan sungai sehingga air meluap. Terdapat dua faktor utama penyebab banjir yaitu faktor alam (natural) dan faktor manusia (man made). Faktor alam seperti tingginya curah hujan, topografi wilayah, pasang surut air sungai Mahakam, dan lain-lain. Faktor alamiah ini sulit untuk dikendalikan, kalaupun bisa memerlukan biaya yang cukup besar.

Faktor kedua adalah manusia, utamanya bersumber pada unsur pertumbuhan penduduk akan diikuti peningkatan kebutuhan infrastruktur, pemukiman, sarana air bersih, pendidkan, serta layanan masyarakat lainnya. Selain itu pertumbuhan penduduk akan diikuti juga kebutuhan lahan usaha untuk pertanian, perkebunan, maupun industry. Kebutuhan 
lahan usaha maupun penyediaan lahan untuk infrastruktur tentu akan mempengaruhi tata guna lahan, dan berdampak pada menurunnya potensi serapan air ke dalam tanah. Selain itu dengan lebih terbukanya lahan maka semakin muda lapisan tanah tergerus air hujan maka sedimentasi akan terjadi di sungai dan akibatnya kapasitas air sungai menurun. Pertumbuhan penduduk tentu akan meningkatkan produksi sampah, apabila pengelolaan sampah tidak baik maka samapah akan menimbulkan masalah antara lain penyumbatan disaluran drainase dan penyumbatan aliran sungai.

Sumber genangan (banjir) di Kota Samarinda khususnya yang dampaknya pada aktivitas masyarakat dapat dibedakan menjadi 3 macam, yaitu :

1. Banjir kiriman, Aliran banjir yang datangnya dari daerah hulu diluar kawasan yang tergenang. Hal ini terjadi jika hujan yang terjadi di daerah hulu menimbulkan aliran banjir yang melebihi kapasitas sungainya sehingga terjadi limpasan. Sebagai contoh lokasi yang sering mendapat banjir kiriman adalah daerah sekitar jalan. Pangeran Antasari. Banjir yang terjadi di daerah atas (hulu) yaitu DAS Manggis dengan durasi 3-4 jam akan dapat menyebabkan banjir di daerah J1. P. Antasari

2. Banjir lokal, genangan air yang timbul akibat hujan yang jatuh di daerah itu sendiri. Hal ini dapat terjadi kalau hujan yang terjadi melebihi kapasitas system drainase yang ada. Pada banjir local, ketinggian genangan air antara 0,2-0,7 m dan lama genangan bisa mencapai 3-5 jam. Tinggi genangan maupun lama genangan akan semakin besar apabila hujan bersamaan dengan pasang sungai Mahakam.

3. Banjir akibat pasang Sungai Mahakam, banjir yang terjadi baik akibat alirat langsung air pasang dan atau air balik dari saluran drainase akibat terhambat oleh air pasang. Banjir pasang merupakan banjir rutin akibat muka air sungai Mahakam pasang. Daerah yang mendapat pengaruh langsung dari air pasang Sungai Mahakam tentunya daerah yang mempunyai ketinggian di bawah muka air pasang sekitar $+1,58 \mathrm{~m}$. Ketinggian genangan antara 0,20-0,50 m dengan lama genangan anatara 2 hingga 4 jam. Pada 5 tahun terakhir sesuai data di atas banjir di Kota Samarinda meningkat baik frekuensi maupun besarannya.

\section{SIMPULAN}

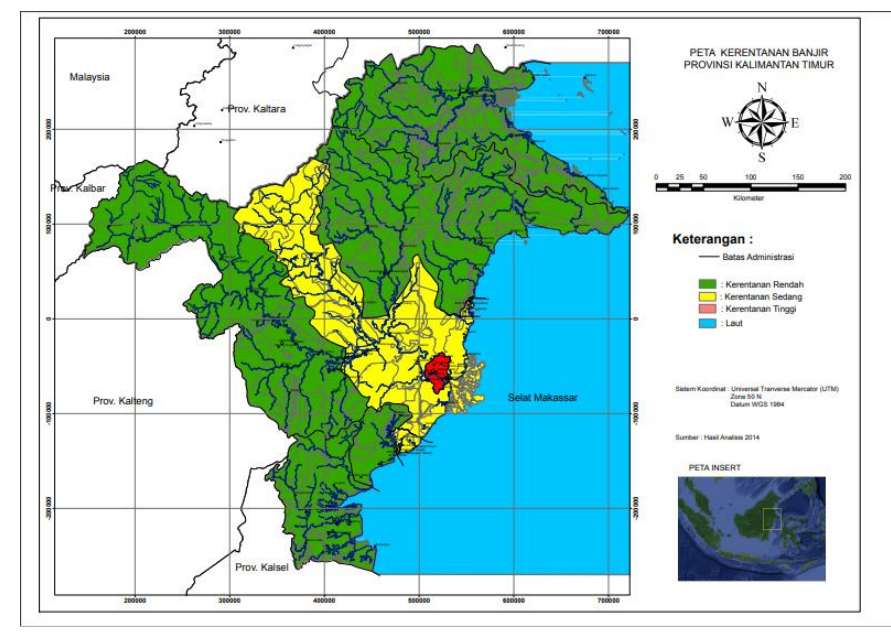

Sumber : BPBD Provinsi Kaltim

Dilihat dari peta di atas bahwasanya Samarinda adalah daerah yang rawan sekali terhadap bencana banjir. Dimana penyeabab banjir permasalahan banjir di Kota Samarinda terjadi akibat berlebihnya limpasan permukaan dan tidak tertampungnya limpasan tersebut dalam badan sungai sehingga air meluap. Ada dua faktor yang menyebabkan banjir di Kota Samarinda yang pertama, Faktor alam seperti tingginya curah hujan, topografi wilayah, pasang surut air sungai Mahakam, dan lainlain. Dan yang kedua, adalah manusia, utamanya bersumber pada unsur pertumbuhan penduduk akan diikuti peningkatan kebutuhan infrastruktur, pemukiman, sarana air bersih, pendidkan, serta layanan masyarakat lainnya. Selain itu pertumbuhan penduduk akan diikuti juga kebutuhan lahan usaha untuk pertanian, perkebunan, maupun industry. Kebutuhan lahan usaha maupun penyediaan lahan untuk infrastruktur tentu akan mempengaruhi tata guna lahan, dan berdampak pada menurunnya potensi serapan air ke dalam tanah. Selain itu dengan lebih terbukanya lahan maka semakin muda lapisan tanah tergerus air hujan maka sedimentasi akan terjadi di sungai dan akibatnya kapasitas air sungai menurun. Sumber genangan (banjir) di Kota Samarinda khususnya yang dampaknya pada aktivitas 
masyarakat dapat dibedakan menjadi 3 macam, yaitu, yang pertama Bajir Kiriman, yang kedua Bajir Lokal, dan Yang ketiga adalah Banjir Akibat Pasang Sungai Mahakam.

\section{REKOMENDASI}

Adapun rekomendasi yang dapat disampaikan agar penelitian selanjutnya dapat lebih baik yakni perlu dilakukannya suatu penelitian lanjutan mengenai data tingkat kecerahan suatu perairan beserta faktor-faktor yang mempengaruhinya.

\section{DAFTAR PUSTAKA}

BPBD (Badan Penanggulangan Bencana). 2014. Indeks Rawan Bencana. Samarinda. BPBD.

\section{Desmawangga, C. 2019. BREAKING NEWS}

Satu Jam Diguyur Hujan, Samarinda Kalimantan Timur Terendam Banjir.https://kaltim.tribunnews.com/20 19/11/19/breaking-news-satu-jamdiguyur-hujan-samarinda-kalimantantimur-terendam-banjir (19 November 2019). Di akses pada: 1 Desember 2019.

Pratiwi dan Ndraha, A. B. 2018. Strategi Pengendalian Banjir di Kota Samarinda Provinsi Kalimantan Timur. Jurnal MSDM Vol.5 No.2 (2 Desember 2018) hal. 141-156.

Rafiq, A., Idris, A. dan Sugandi. 2014. Studi tentang Kebencanaan dalam Penanggulangan Bencana Banjir di Kota Samarinda Pada Badan Penanggulangan Bencana Daerah (BPBD) Provinsi Kalimantan Timur. eJournal Administrative Reform, Vol.2 (3) hal:1548-1560.
Sartika, D. 2019. Pengelolaan Banjir Di Kota Samarinda Berbasis Pemberdayaan Masyarakat Melalui Sumur Biopori. Jurnal Kebijakan Pembangunan Vol.14 No.1 (Oktober) hal.63-76.

Sodik, F. 2015. Upaya Pemerintah dalam Pengendalian Banjir di Kota Samarinda. eJournal Ilmu Pemerintahan, Vol. 3 (2) hal:782-796.

Sugiono. 2012. Metode Penelitian Kuantitatif Kualitatif dan $R \& D$. Bandung: Alfa Beta.

Susila, I., Putra, I. dan Buana, P. W. 2017. Rancang Bangun Aplikasi Analisa Pola Hujan Penyebab Banjir Di Jakarta. Jurnal Ilmiah Merpati (Menara Penelitian Akademika Teknologi Informasi) Vol.3 No.3 (Desember 2017). 11. 10.24843/JIM.2017.v05.i03.p01.

Syahrul, A. 2014. Analisis Dampak Banjir Pada Tahun 2007 Terhadap Pelaksanaan Pendidikan Sekolah dan Kesiapsiagaan Masyarakat Dalam Bencana Banjir Di Kelurahan Joyotakan Kecamatan Surakarta. Skripsi thesis, Universitas Muhammadiyah Surakarta.

Yovanda. 2019. Banjir Lagi di Jalanan Kota Samarinda.https://news.detik.com/berita /d-4789936/banjir-lagi-di-jalanan-kotasamarinda (19 November 2019). Di akses pada: 1 Desember 2019. 